Volume No. 1, Issue No. 2 (April- June) pp. 79-94

\title{
On The Use of Cloud Computing in Educational Institutions - A Survey
}

Namrah Khurram

\begin{abstract}
Pakistan has the potential of producing intellectual individuals that help in contributing for the better of the world through their knowledge and skills. There can be many opportunities created and built for the education sector through the introduction of advanced technologies for educational purposes. Hence, there is a rapid need for the adoption of cloud-based learning environment in the institutions in Pakistan for a better learning and a better tomorrow. This paper presents a survey of some of the universities in the metropolitan cities of the country and discusses the approach and environment that has been established in those institutions for learning purposes. A survey was carried out, it was then analyzed, the current situation was observed and conclusions for a better learning environment were then discussed. The survey and analysis of was carried out to see how education at school level is delivered and how it is done at university level which would help in creating a stronger base at primary and intermediate levels. It is expected that this study will help future research work when looking into the cloud based learning environments in the educational institutions of Pakistan and ways in which it can be improved and taken to a higher level.
\end{abstract}

Keywords-cloud computing in education, developing countries education, Pakistan education sector, cloud storage, remote learning

\section{INTRODUCTION}

The trend of cloud computing is relatively new in Pakistan. Schools and universities in Pakistan are still undergoing this change of adapting to the new

Namrah Khurram MS (CS) SEECS-NUST, Islamabad, Pakistan environment. This is mainly because of the initial high-budget for implementation of such a system and secondly because of the scarce resources available to them. Universities which are well established 
for over a couple of decades now have adopted the cloud systems in their educational environments where they provide students and faculty members with on-demand storage, on-demand scalability and online services anywhere and anytime through their powerful webbased tools.

In Pakistan, the private sector universities are major adapters of cloud computing. Where very few schools have even partially adopted the cloud infrastructure, they are still progressing towards better education through the implementation of SMART boards. These are interactive white boards which let the faculty deliver interactive dynamic lessons, take notes on screen with digital ink and let them save their work with just a swipe of a finger on the board. Institutions have also been greatly seen as adopting the email domains from the Gmail server, using that as their official institution mailing system.

Keeping all these factors in mind along with the dire need of quality education in third world countries like Pakistan, a survey was carried out targeting the schools, colleges and universities of the metropolitan cities of Pakistan; Lahore, Islamabad and Karachi. Visits were made to various IT departments of different educational institutions and one-on-one open-ended interviews were conducted with IT personnel as well as students, to get to know the basic infrastructure and the use of technology and cloud within the institution's educational needs and requirements.

The main motive behind this survey was to find out the current progress in the education sector in Pakistan with respect to the use of cloud computing in their institutional environment along with extent to which the cloud been has adapted by students and faculty members and how has it benefited them in comparison with the conventional teaching and learning environment. It was greatly seen that even if the cloud system was not functional in institutions, they still were making full utility of the available resources and facilities provided by the internet and the World Wide Web on it.

This paper has been divided into five more sections after this where section II includes all the work related to cloud environments in developing countries, in Pakistan and cost and benefit analysis of 
the cloud. Section III consists of the whole survey and its findings, further divided into a few subsections for a detailed presentation of the work done and conclusions drawn. A cloud model of a university has been studied in detail in section IV. Conclusions have been made in section $\mathrm{V}$ along with a discussion of future work in section VI.

\section{RELATED WORK}

In this section, a systematic literature review has been carried out on current cloud environment setup and maintenance in educational institutions of both Pakistan and the third world developing countries in general.

\subsection{Use of Cloud in Education in Developing Countries:}

In [1] the authors have put light upon how institutions, their students, faculty as well as researchers can benefit from the use of cloud and cloud services in attaining their goals. A study has been carried out on this and Vietnam's education and research sector has been presented as a case study on a general note for developing countries. The authors have presented potential benefits of cloud computing in education and research which includes a private cloud model for virtualizing the laboratories and teaching environment. SaaS, PaaS, IaaS and DaaS (Data as a Service) models have been proposed in this paper, each catering to a different target audience.

However, the barriers need to be considered too especially keeping in mind that all the propositions are for developing countries - countries with scarce resources and fund, minimal budgets for education and a poor economy governed by highly inefficient government body. In countries like these there is a problem of power supply, scant bandwidth and instable connections. Moreover, if the cost is calculated it will still be an expensive setup for developing countries.

A cloud computing framework has been proposed in [2] for Ethiopian Higher Education Institutions. The framework named "Ethiopian Universities Hybrid Cloud (EUHC)" has been proposed which will be utilizing the existing IT infrastructure of the universities and institutions there. This framework was proposed to be adapted through the deployment of the hybrid cloud model which was to chain the local infrastructure 
as a private cloud with nominated few public clouds. Although the framework was proposed keeping in mind the economic and financial conditions of the country, there are limitations of available resources and budget issues when it comes to implementation of this framework.

\subsection{IT \& Cloud Computing in Education in Pakistan:}

A study was carried out to explore the impacts that IT has on the e-learning process within Pakistan in [3]. "Allama Iqbal Open University (AIOU)" and "Virtual University Pakistan (VUP)" were the highlights of the paper. These two institutions are using the IT infrastructure and cloud for learning and education purposes not only for students and teachers, but also for trainers and trainees of different fields of professions.

If this sort of a system is adapted throughout the education sector - private and public, then learning will become secure through the cloud as every institution can develop their own. The paper also suggests the use of cellular phone networks for e-education but not every student owns a smart phone in the country. Hence, this solution has glitches that need to be addressed first.

\subsection{Virtual Education and Distance Learning in Pakistan:}

Students' attitude towards virtual education in Pakistan has been presented in [4]. From the evaluation, it was concluded that students consider this as an alternate formal education method which has been adapted well among them. One of the main reasons a positive feedback was given was because of the facility of flexible learning timings and materials readily available to them at any time of the day or night. Along with that, this system provided students and instructors with a worthy exposure of the incipient technologies. A learning management system (LMS) has also been deployed by the university to facilitate the students to the full possible extent and tags along a moderated discussion board (MDB) for peer-to-peer communication and discussions with professors also.

$94 \%$ of the people surveyed strongly supported the need for virtual education systems and also stated that it is one of the best ways that might extend opportunities of higher education. However, such a 
system in Pakistan faces major security concerns and issues such as password hacking, the development of computer vision syndrome (CVS) due to excessive use of systems for learning purposes, other joint pains and of course electricity supply failure.

\subsection{Cost and Benefit of Cloud in Education:}

Analysis of costs and the benefits of cloud computing in education is an essential area to be researched upon and explored when implementing such a system. In [5], a comparison of Total Cost vs. Cost of use per month has been carried out as a model based study for over a period of 30 years. One major benefit of the cloud is the eradication of maintenance of the conventional computing infrastructure. It is an effective implementation for the long run, lifting the burden of taking care of complex IT infrastructures in educational institutions. Benefits such as jobs in remote learning through the cloud will also provide opportunities for the unemployed.

To actually achieve the benefits of cloud computing, it is also essential to investigate how academics think about the integration of such services into the educational system which has been discussed in [6]. This can only be achieved if both the students and the institutions are supportive of new learning methodologies.

\subsection{Challenges of Cloud Computing in Education:}

The authors in [7] highlight the advantages that come with integration of the cloud computing in education, the costs associated with is and the challenges tagged alongside which may cause hindrances in its adaptations. Where the cloud provides efficient data management for institutions and research advancement opportunities for students, it also raises concerns of security and privacy. However, enforcement of efficient policies and techniques can eliminate these drawbacks and challenges.

In [8] , the authors highlight the challenges faced in Malaysia in the use of cloud computing in higher education. This can be applied elsewhere also, especially in Pakistan where similar difficulties are faced like problems with efficiency and speed of internet access which has a direct impact on the use of this technology. Lack 
of expertise is also another problem which has a direct implication on the implementation of this technology and in general emerging technologies.

\section{SURVEY OF MAJOR EDUCATIONAL INSTITUTIONS OF PAKISTAN - PRIVATE \& PUBLIC}

A survey was carried out of the major universities across the three metropolitan cities of Pakistan. The main motive and object behind this survey, as mentioned earlier, was to find out the current progress in the education sector in Pakistan with respect to the use of cloud computing in their institutional environment. The objective was basically to know the extent of cloud adoption by the educational institutions, the benefits which have been seen as a result and possible improvements and enhancements that can be proposed keeping in mind the feedback of students in these institutions.

The following 11 universities and colleges were included in the survey, out of which 4 are private sector universities and the remaining 7 are public sector universities, spread over the three major metropolitan cities of Pakistan:
Table 1: List of universities/colleges included in the survey

\begin{tabular}{|c|c|c|}
\hline Name & City & Sector \\
\hline $\begin{array}{l}\text { Lahore University } \\
\text { of Management } \\
\text { Sciences (LUMS) }\end{array}$ & Lahore & Private \\
\hline $\begin{array}{l}\text { National } \\
\text { University of } \\
\text { Computer and } \\
\text { emerging } \\
\text { Sciences (NU- } \\
\text { FAST) } \\
\end{array}$ & $\begin{array}{l}\text { Lahore, } \\
\text { Islamabad, } \\
\text { Karachi }\end{array}$ & Private \\
\hline $\begin{array}{l}\text { Kinnaird College } \\
\text { for Women }(K C)\end{array}$ & Lahore & Public \\
\hline $\begin{array}{l}\text { Lahore College } \\
\text { for Women } \\
\text { University } \\
\text { (LCWU) }\end{array}$ & Lahore & Private \\
\hline $\begin{array}{l}\text { Lahore School of } \\
\text { Economics (LSE) }\end{array}$ & Lahore & Private \\
\hline $\begin{array}{l}\text { University of } \\
\text { Engineering and } \\
\text { Technology } \\
\text { (UET) }\end{array}$ & Lahore & Public \\
\hline $\begin{array}{l}\text { Air University } \\
\text { (Pakistan Air } \\
\text { Force) }\end{array}$ & Islamabad & Public \\
\hline $\begin{array}{l}\text { International } \\
\text { Islamic } \\
\text { University (IIU) }\end{array}$ & Islamabad & Public \\
\hline $\begin{array}{l}\text { Virtual } \\
\text { University of } \\
\text { Pakistan (VUP) }\end{array}$ & $\begin{array}{l}\text { Lahore, } \\
\text { Islamabad, } \\
\text { Karachi }\end{array}$ & Public \\
\hline $\begin{array}{l}\text { National } \\
\text { University of } \\
\text { Sciences and } \\
\text { Technology } \\
\text { (NUST) }\end{array}$ & Islamabad & Public \\
\hline $\begin{array}{l}\text { COMSATS } \\
\text { Institute of } \\
\text { Information } \\
\text { Technology }\end{array}$ & Islamabad & Public \\
\hline
\end{tabular}


The schools included in the survey are as follows:

Table 2: List of Schools included in the survey

\begin{tabular}{|l|l|l|}
\hline Name & City & Sector \\
\hline $\begin{array}{l}\text { Convent of Jesus \& } \\
\text { Mary }\end{array}$ & Lahore & Private \\
\hline $\begin{array}{l}\text { Lahore Grammar } \\
\text { School }\end{array}$ & Lahore & Private \\
\hline Learning Alliance & Lahore & Private \\
\hline
\end{tabular}

\section{METHODOLOGY: DATA COLLECTION PROCESS}

The target institutions for the survey were the ones established in Lahore, Islamabad and Karachi. For the listed universities and schools (see Table 1 and Table 2), the data was collected in various ways which included one-to-one interviews with students and the IT personnel, and telephonic interviews also (see Table 3). The questions asked were not all closeended. It was a series of semi open-ended interviews where a list of questions were presented and the interviewees were also welcomed to add more detail or share any extra information that they find useful and helpful in carrying out this research.

Students were particularly asked questions about their feelings and concerns about the current education system, the IT infrastructure of their respective institutions and their suggestions for improving the situation. Table 3 shows details of the interviews conducted in a tabular form below.

For privacy purposes, the names of universities, colleges and schools have not been disclosed from here onwards of the survey and referred as 'UNIVERSITY 1' and so on.

Table 3: Details of the interviews conducted

\begin{tabular}{|c|c|c|}
\hline $\begin{array}{l}\text { University/ } \\
\text { School }\end{array}$ & Interviewees & $\begin{array}{l}\text { Interview } \\
\text { Mode }\end{array}$ \\
\hline $\begin{array}{l}\text { UNIVERSI } \\
\text { TY } 1\end{array}$ & $\begin{array}{l}\square \\
\text { Faculty/Ad } \\
\text { ministration } \\
\text { 冈Students } \\
\end{array}$ & $\begin{array}{l}\text { \One to One } \\
\square \text { Telephone } \\
\square \text { Email }\end{array}$ \\
\hline $\begin{array}{l}\text { UNIVERSI } \\
\text { TY } 2\end{array}$ & $\begin{array}{l}\square \\
\text { Faculty/Ad } \\
\text { ministration } \\
\bigotimes \text { Students }\end{array}$ & $\begin{array}{l}\text { 囚One to One } \\
\text { Telephone } \\
\text { Email }\end{array}$ \\
\hline $\begin{array}{l}\text { UNIVERSI } \\
\text { TY } 3\end{array}$ & $\begin{array}{l}\square \\
\text { Faculty/Ad } \\
\text { ministration } \\
\text { 冈Students }\end{array}$ & $\begin{array}{l}\text { XOne to One } \\
\text { TTelephone } \\
\square \text { Email }\end{array}$ \\
\hline $\begin{array}{l}\text { UNIVERSI } \\
\text { TY } 4\end{array}$ & $\begin{array}{l}\otimes \\
\text { Faculty/Ad } \\
\text { ministration } \\
\square \text { Students }\end{array}$ & $\begin{array}{l}\square \text { One to One } \\
\text { Telephone } \\
\square \text { Email }\end{array}$ \\
\hline $\begin{array}{l}\text { UNIVERSI } \\
\text { TY } 5\end{array}$ & $\begin{array}{l}\square \\
\text { Faculty/Ad } \\
\text { ministration } \\
\text { 冈Students }\end{array}$ & $\begin{array}{l}\text { 囚One to One } \\
\square \text { Telephone } \\
\text { Email }\end{array}$ \\
\hline
\end{tabular}




\begin{tabular}{|c|c|c|}
\hline $\begin{array}{l}\text { UNIVERSI } \\
\text { TY } 6\end{array}$ & $\begin{array}{l}\square \\
\text { Faculty/Ad } \\
\text { ministration } \\
\text { 邓Students }\end{array}$ & $\begin{array}{l}\bigotimes \text { One to One } \\
\square \text { Telephone } \\
\square \text { Email }\end{array}$ \\
\hline $\begin{array}{l}\text { UNIVERSI } \\
\text { TY } 7\end{array}$ & $\begin{array}{l}\square \\
\text { Faculty/Ad } \\
\text { ministration } \\
\text { \Students }\end{array}$ & $\begin{array}{l}\bigotimes \text { One to One } \\
\square \text { Telephone } \\
\bigotimes \text { Email }\end{array}$ \\
\hline $\begin{array}{l}\text { UNIVERSI } \\
\text { TY } 8\end{array}$ & $\begin{array}{l}\square \\
\text { Faculty/Ad } \\
\text { ministration } \\
\text { 邓Students }\end{array}$ & $\begin{array}{l}\bigotimes \text { One to One } \\
\square \text { Telephone } \\
\bigotimes \text { Email }\end{array}$ \\
\hline $\begin{array}{l}\text { UNIVERSI } \\
\text { TY } 9\end{array}$ & $\begin{array}{l}\square \\
\text { Faculty/Ad } \\
\text { ministration } \\
\text { \Students }\end{array}$ & $\begin{array}{l}\square \text { One to One } \\
\bigotimes \text { Telephone } \\
\square \text { Email }\end{array}$ \\
\hline $\begin{array}{l}\text { UNIVERSI } \\
\text { TY } 10\end{array}$ & $\begin{array}{l}\text { 叉 } \\
\text { Faculty/Ad } \\
\text { ministration } \\
\text { \Students }\end{array}$ & $\begin{array}{l}\bigotimes \text { One to One } \\
\square \text { Telephone } \\
\square \text { Email }\end{array}$ \\
\hline $\begin{array}{l}\text { UNIVERSI } \\
\text { TY } 11\end{array}$ & $\begin{array}{l}\text { \aculty/Ad } \\
\text { ministration } \\
\text { \Students }\end{array}$ & $\begin{array}{l}\bigotimes \text { One to One } \\
\bigotimes \text { Telephone } \\
\bigotimes \text { Email }\end{array}$ \\
\hline School 1 & $\begin{array}{l}\text { 叉 } \\
\text { Faculty/Ad } \\
\text { ministration } \\
\text { \Students }\end{array}$ & $\begin{array}{l}\bigotimes \text { One to One } \\
\square \text { Telephone } \\
\square \text { Email }\end{array}$ \\
\hline School 2 & $\begin{array}{l}\square \\
\text { Faculty/Ad } \\
\text { ministration } \\
\text { 冈Students }\end{array}$ & $\begin{array}{l}\bigotimes \text { One to One } \\
\square \text { Telephone } \\
\bigotimes \text { Email }\end{array}$ \\
\hline School 3 & $\begin{array}{l}\text { 区 } \\
\text { Faculty/Ad } \\
\text { ministration } \\
\square \text { Students }\end{array}$ & $\begin{array}{l}\bigotimes \text { One to One } \\
\square \text { Telephone } \\
\square \text { Email }\end{array}$ \\
\hline
\end{tabular}

\section{FINDINGS \& RESULTS}

After the data was collected, it was analyzed closely for finding out the current cloud environments prevalent in the mentioned universities and schools, and improvements that were required. Interviews were conducted for each of the universities and schools listed. It was observed that the top-notch universities among the listed ones were the ones with some form of cloud implementation. Other universities, which haven't made to top ranks, some did not have even a basic cloud setup and only a few were taking benefit of the facility of the internet in some form for delivering information and communicating with students.

Table 4 shows an overall summary of the survey that was carried out in universities. Among these, UNIVERSITY 1, 2, 9, 10 and 11 are the only ones with a cloud based learning environment. Moreover, other than these five, only UNIVERSITY 8 is using a Learning Management System (LMS). It was not actually an LMS, it was called a VLE where students could log in and see course information, submit assignments and see who else was online on the portal. According to the student feedback received it was a very slow system which they refused to adopt as it did not facilitate them in any way. To be 
more precise, one of the students questioned on adoption of VLE said that it had a 'bad interface' that made it a lot more difficult to even use it.

Institutes like UNIVERSITY 4 and 7 were seen to be still working in the era of no computers. Everything from the assignments submissions to the examination results was seen to be done manually. According to the administration an LMS like setup was introduced but it was not a well-built design and architecture thus resulted in a failure.

UNIVERSITY 9 and 11 are the only two universities that have the facility of a distance/remote learning environment. This is something that needs to be established as one of the most essential requirements in a cloud based learning environment so that people who cannot get enrolled as regular students in the institutions during the day time can still study and learn more while working. The flexible timings only add to the list of benefits this type of an environment has.

Table 4: An overall summary of the type of cloud environment in the listed universities

\begin{tabular}{|c|c|c|c|c|c|c|c|c|c|c|c|}
\hline & 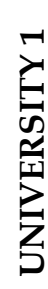 & 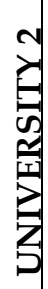 & 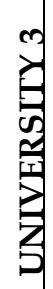 & 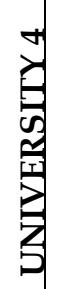 & 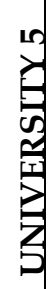 & $\begin{array}{l}0 \\
7 \\
0 \\
\frac{7}{9} \\
\frac{7}{3} \\
3\end{array}$ & 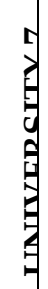 & 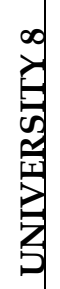 & 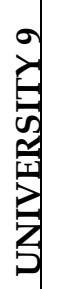 & 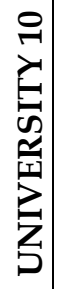 & 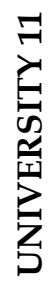 \\
\hline $\begin{array}{l}\text { Clou } \\
\text { d } \\
\text { (SaaS, } \\
\text { PaaS } \\
\text { or } \\
\text { IaaS) }\end{array}$ & $\checkmark$ & $\checkmark$ & $x$ & $x$ & $x$ & $x$ & $x$ & $x$ & $\checkmark$ & $\checkmark$ & $\checkmark$ \\
\hline $\begin{array}{l}\text { Data } \\
\text { Cente } \\
r\end{array}$ & $\checkmark$ & $\checkmark$ & $x$ & $x$ & $x$ & $x$ & $x$ & $x$ & $\checkmark$ & $\checkmark$ & $\checkmark$ \\
\hline $\begin{array}{l}\text { Indep } \\
\text { ende } \\
\text { nt } \\
\text { Email } \\
\text { Dom } \\
\text { ain }\end{array}$ & $\checkmark$ & $\checkmark$ & $\checkmark$ & $x$ & $x$ & $x$ & $\mathbf{x}$ & $x$ & $\checkmark$ & $\checkmark$ & $\checkmark$ \\
\hline $\begin{array}{l}\text { Gmai } \\
1 \\
\text { Serve } \\
\text { rs } \\
\text { Dom } \\
\text { ain } \\
\text { for } \\
\text { Email }\end{array}$ & $\begin{array}{l}\mathrm{N} \\
/ \\
\mathrm{A}\end{array}$ & $\begin{array}{l}\mathrm{N} \\
/ \\
\mathrm{A}\end{array}$ & $\checkmark$ & $x$ & $x$ & $x$ & $\checkmark$ & $\checkmark$ & $\begin{array}{l}\mathrm{N} \\
/ \\
\mathrm{A}\end{array}$ & $\begin{array}{l}\mathrm{N} \\
/ \\
\mathrm{A}\end{array}$ & $\begin{array}{l}\mathrm{N} \\
/ \\
\mathrm{A}\end{array}$ \\
\hline LMS & $\checkmark$ & $\checkmark$ & $x$ & $x$ & $x$ & $x$ & $x$ & $\checkmark$ & $\checkmark$ & $\checkmark$ & $\checkmark$ \\
\hline $\begin{array}{l}\text { Onlin } \\
\mathrm{e} \\
\text { Assig } \\
\text { nmen } \\
\mathrm{t}\end{array}$ & $\checkmark$ & $\checkmark$ & $x$ & $x$ & $x$ & $x$ & $\mathbf{x}$ & $\checkmark$ & $\checkmark$ & $\checkmark$ & $\checkmark$ \\
\hline
\end{tabular}




\begin{tabular}{|l|l|l|l|l|l|l|l|l|l|l|l|}
\hline $\begin{array}{l}\text { Subm } \\
\text { ission }\end{array}$ & & & & & & & & & & & \\
\hline $\begin{array}{l}\text { Onlin } \\
\text { e } \\
\text { Resul } \\
\text { ts }\end{array}$ & $\checkmark$ & $\checkmark$ & $\checkmark$ & $\times$ & $\checkmark$ & $\times$ & $\times$ & $\checkmark$ & $\checkmark$ & $\checkmark$ & $\checkmark$ \\
\hline $\begin{array}{l}\text { Dista } \\
\text { nce } \\
\text { Learn } \\
\text { ing }\end{array}$ & $\times$ & $\times$ & $\times$ & $\times$ & $\times$ & $\times$ & $\times$ & $\times$ & $\checkmark$ & $\times$ & $\checkmark$ \\
\hline
\end{tabular}

The schools surveyed did not have any sort of cloud infrastructure. Nonetheless, they did show some progress towards the advancements in technology and the need for technology to be integrated in the educational environment. Smart board is one such area, which is being adopted by schools now (see Table 5). Because of its high costs, not many schools have implemented this system but out of the three schools surveyed, two of them have partially implemented the use of smart boards in classrooms for teaching purposes.

Table 5 also shows that School 3 have progressed further into adopting technology and advancing into the new era of providing better learning opportunities. They have used Gmail Domain as a means of official communication between the students, faculty and peer-to-peer communication. An online portal, like an LMS, has also been designed for the ease of students in School 3. Learning materials and subject announcements as well as other announcements related to the school are made there. Emails are also sent to the students on their official school Gmail accounts for announcements.

Table 5: Overall summary of the learning environment tools in the listed schools

\begin{tabular}{|c|c|c|c|c|c|}
\hline & $\frac{\bar{\sigma}}{\tilde{U}}$ & $\sum_{,}^{\infty}$ & 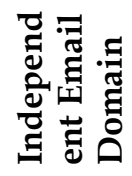 & 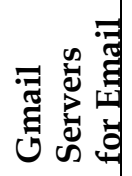 & 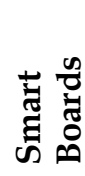 \\
\hline School 1 & $x$ & $x$ & $x$ & $x$ & $x$ \\
\hline School 2 & $x$ & $x$ & $x$ & $x$ & $\checkmark$ \\
\hline School 3 & $x$ & $\checkmark$ & $x$ & $\checkmark$ & $\checkmark$ \\
\hline
\end{tabular}

Overall, it was found that the cloud-based learning environment in educational institutions of Pakistan still seems to be a developing concept. It is a relatively new concept and is still in the process of being implemented and adopted by institutions throughout the country. The process of moving towards the cloud is a gradual process but at present it is going at an extremely slow pace, with resistance and 
hesitation seen due to a lot of factors out of which the major contributing factor is the cost of implementation.

\section{ANALYSIS \& EVALUATION}

Pakistan, being a developing country, still has state of the art universities and learning infrastructures where people come and study not only from all the corners of the country but a large number of foreign students can also be seen in medical and engineering universities in particular. This means that Pakistan has the potential of producing talented and intellectual brains through the dedicated education and hard work provided by the teachers.

From the results of the survey it was evaluated that there is a gradual switch over being seen among the universities and colleges in Pakistan from the manual systems to the cloud but it is rather a very slow process which is going to take a lot of time, effort and convincing power. The major reason for this is the cost that is needed for the implementation, the lack of monetary support that the government should be providing to these institutions along with a lack of awareness of cloudbased education. It was seen that some institutions have not even made use of the facility of the internet which is available all over the country for over two decades now. Introducing a very basic level system integrated with the internet will be a step towards the rise in motivation and conviction of the students towards a better learning.

\subsection{Cloud at University 1:}

UNIVERSITY 1 has one of the most wellestablished cloud systems integrated into their educational environment. On a closer look at this full scale cloud model, it was found that there are various

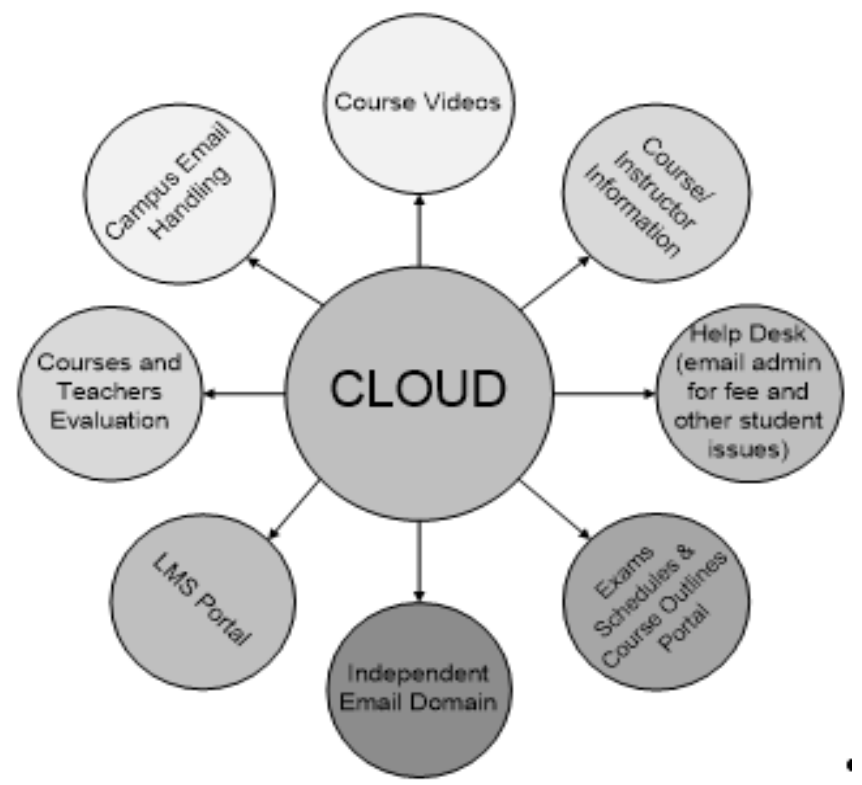

Figure 1: The cloud components at UNIVERSITY 1 domains handling a variety of tasks for 
both the students and the administration. The powerful data centers running seamlessly throughout the year provide efficient storage and management of data along with security of information there. The cloud model has various components (Fig. 1) which together shape it into the best possible facilitation and ease provided for everyone - the students, the faculty and the administration.

With the data centers working round the clock, aided with full-time back-up power supply, the cloud infrastructure was introduced in UNIVERSITY 1. This system helps students in many ways such as availability of course contents, lecture videos, fee issues and not to forget a help desk email system working all day to handle the queries and inquiries from the student body there. The instructors are also aided with their own space on the cloud, to manage and administer various activities, provide content to students and be able to communicate with them through the portal for questions, results and feedback. The administration makes use of the cloud in ways like making mass announcements, portals for course outlines and examination schedules etc.

There are eight major components of the cloud system implemented in UNIVERSITY 1. The institute has its own independent email domain. The online Learning Management System (LMS) has been designed for the students, accessible at any time from any location, where all the learning content is available such as lecture slides, assignment submissions etc. Course registrations, hostel accommodation applications and registrations and instructor evaluations for various courses are all done online at 'zambeel' domain name. For handling emails of students, 'campusmail' has been made available. Every student, faculty member and the administrations staff has their own accounts which they use for fulfillment of their tasks and jobs.

There also exists another portal where course outlines, class and examination schedules are made available for the students. Helpdesk too has an email which is provided to the students to email the administration with their issues related to fee or any other queries that are needed to be addressed to the administration. The domain 'ponapto' provides all the lecture videos which are delivered inside the premises of UNIVERSITY 1 and are made available to the students by logging 
in to that portal. The instructors are provided space at the domain name 'suraj' where they have their own webpage. Instructor's information and achievements are listed there along with any course content that the instructor wishes to upload.

The university has a very versatile cloud and IT infrastructure. The institute has made the best possible efforts in facilitating its students and the staff. The cloud model presented in this paper shows how deeply the system runs to help students become better learners and aids the faculty in delivering and administering their courses in the most efficient ways possible.

The only component missing on the list for UNIVERSITY 1, as said by students also during the survey, is the non-presence of a remote/distance learning environment. According to the students, if that is made possible then UNIVERSITY 1 would generate a wave of elevated motivation amongst students especially the ones who are working and cannot get enrolled there for a fixed timeslot during the day. It will only facilitate the students more, which will result in a much better outcome than it already is.

\section{CONCLUSION}

From the survey that was conducted, it was well-observed that the education sector in Pakistan is growing by the day and is keeping up well with the introduction of new technologies and modern aids that help in better learning and delivering of information and education. Nevertheless, one important factor is that growth is being seen more where the institutions are well-established over the spread of around a decade. The government sector colleges and schools in particular still do not have the basic requirements fulfilled for education. Those institutions still lack the proper basic infrastructure for studying let alone the implementation of some IT or cloud environment. With these barriers in place it is a highly complex task to introduce any advanced technology or learning environment. The government needs to pay special attention to the education system currently prevailing in Pakistan and maximum budget allotments should be made to this sector. If this sector will grow and rise, only then will the country rise.

One thing, which can be said to be a major contributor towards better education, is 
awareness campaigns. There is a lack of awareness among students that are forced to switch to an LMS or a cloud system in general suddenly. Instead of a sudden implementation and switch over, it is more favorable that students and staff are made aware of the switch over through various workshops and seminars along with hands-on labs and training on how to handle, store and access data in a cloudbased environment. With a gradual switch over rather than an abrupt one, the problems of not adapting well to this environment will be eliminated as the main reason behind the resistance is lack of awareness.

There are various useful components in different cloud environments of the variety of universities included in this survey. If the basic infrastructure is well built and in place and there is a proper amount allocated to the education in the government's budget, along with proper trainings and tutorials on the usage of this learning environment, then a cost effective and efficient cloud system can be designed for future which will include the best facilities and components brought together under one system, implemented on an initial smaller scale and then takes farther into the roots of the education sector and leaning environment in the public and private institutions of Pakistan.

\section{DISCUSSION AND FUTURE WORK}

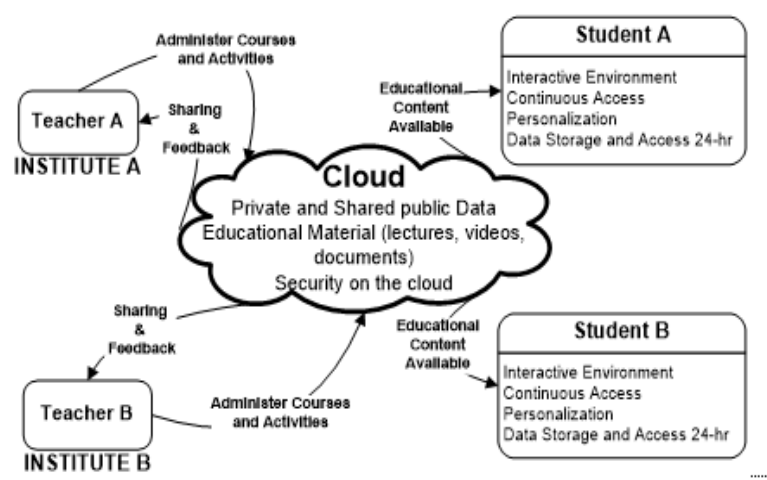

Figure 2: a general idea of a small-scale cloud environment

This paper was not only written for the purpose of presenting the survey results, rather the aim was to help future research and development in this area through the information that was gathered over the survey. This information will work as an aid, an input and hopefully a contribution towards designing of a better, cost effective and beneficent cloud environment not only for Pakistan but for developing countries in general also.

For future work, this survey shall be kept in mind and the idea is to design a cloud 
system such that it is implementable on a small scale in educational institutions on low budgets. Funding, if provided, can help design and set up a small, general cloud environment, which can be deployed on smallest possible scales as a start towards the cloud revolution in educational institutions of Pakistan.

Fig. 2 presents a general idea of a small but a generic cloud based learning environment, where different institutions should be able to implement it within their financial capacities as a start towards providing this facility. This is only a skeleton diagram, a very general idea that needs to be worked upon and it shall be encouraged that this be taken further by any researcher or student who can add to it for the benefit of Pakistan, developing countries and the students all around the world. 
(ICCCA), 2012 International

\section{References}

[1] N. T. S. D. Hong-linh Truong, "Cloud Computing for Education and Research in Developing Countries," IGI Global, 2012.

[2] Shaikh Saidhbi, "A Cloud Computing Framework for Ethiopian Education Institutions," IOSR Journal of Computer Engineering (IOSRJCE), vol. 6, no. 6, pp. 01 - 09, Nov - Dec 2012.

[3] A. A. A. W. S. A. B. M. Ali, "Impacts of Information Technology on eLearning System in Pakistan," Sindh University Resource Journal, vol. 43, pp. 29 - 34, 2011.

[4] Dr. Irshad Hussain, "A Study of Student's Attitude towards Virtual Education in Pakistan," Turkish Online Journal of Distance Education-TOJDE , vol. 8, April 2007.

[5] M. B. D.G. Chandra, "Cost Benefit Analysis of Cloud Computing in Education," in Computing, Communication and Applications
Conference, 2012.

[6] I. Arpaci, "Antecedents and consequences of cloud computing adoption ineducation to achieve knowledge management," Computers in Human Behavior, Elsevier, vol. 70, pp. 382-390, 2017.

[7] C. Bulla, B. Hunshal and S. Mehta, "Adoption of Cloud Computing in Education System: A Survey," IJESC, vol. 6, no. 6, pp. 6375-6380, June 2016.

[8] A. Shahzad, A. G. Golamdin and N. A. Ismail, "Opportunity and Challenges Using The Cloud Computing In The Case Of Malaysian Higher Education Institutions," in 6th Annual American Business Research Conference, New York, USA, June 2014. 